\title{
Aglaonema costatum f. concolor Nicolson (ARACEAE): A NEW RECORD FOR THE FLORA OF VIETNAM
}

\section{Luu Hong Truong ${ }^{1, *}$, Van Hong Thien ${ }^{2}$, Bui Ngoc Thanh ${ }^{3}$, Le Thuan Kien ${ }^{3}$, Truong Quang Cuong ${ }^{4}$, Le Canh Nam ${ }^{5}$}

${ }^{1}$ Southern Institute of Ecology, VAST, Vietnam

${ }^{2}$ Institute of Biotechnology and Food technology, Industrial University of Ho Chi Minh city,

Ho Chi Minh city, Vietnam

${ }^{3}$ Phong Nha - Ke Bang National Park, Quang Binh, Vietnam

${ }^{4}$ Bidoup - Nui Ba National Park, Lam Dong, Vietnam

${ }^{5}$ Forest Science Institute of Central Highlands and South of Central Vietnam,

Lam Dong, Vietnam

Received 31 January 2019, accepted 10 May 2019

\begin{abstract}
Aglaonema costatum f. concolor is reported as a new record for the flora of Vietnam. The taxon was recently found in Phong Nha - Ke Bang National Park, Quang Binh Province. It is illustrated with detailed photographs of key morphological characters taken from the field. A key to all known taxa of Aglaonema in Vietnam is given.
\end{abstract}

Keywords: Araceae, Aglaonema costatum f. concolor, new record, Vietnam.

Citation: Luu Hong Truong, Van Hong Thien, Bui Ngoc Thanh, Le Thuan Kien, Truong Quang Cuong, Le Canh Nam, 2019. Aglaonema costatum f. concolor Nicolson (Araceae): a new record for the flora of Vietnam. Academia Journal of Biology, 41(3): 61-65. https://doi.org/10.15625/2615-9023/v41n3.13595.

*Corresponding author email: hongtruongluu@ gmail.com

(C2019 Vietnam Academy of Science and Technology (VAST) 


\section{INTRODUCTION}

The genus Aglaonema Schott (Araceae) has about 23 species belonging to two sections (Chamaecaulon and Aglaonema) with distributions from the subtropical eastern Himalaya throughout tropical and subtropical Asia as far east as New Guinea (Nicolson, 1969; Boyce et al., 2012). Sect. Chamaecaulon is characterized by creeping rhizomatous stem and includes three species: A. brevispathum (Engl.) Engl., A. costatum N.E.Br. (type of the section) and $A$. chermsiriwattanae D.Sookchaloem. The last species is distinguishable from the other two by the absence of cataphyll/prophyll subtending petiole. Meanwhile, the first two species look alike and $A$. brevispathum differs from $A$. costatum in having marcescent cataphyll/prophyll subtending petiole, petiole usually equaling or exceeding the leaf blade and usually obtuse to subrounded leaf base (vs. immediately deliquescent cataphyll/prophyll subtending petiole, petiole usually shorter than leaf blade and usually subcordate to rounded leaf base). According to Nicolson (1969), A. costatum includes 4 forms that can be distinguishable by the following key:

1A. Leaf-blade with a white midrib.

.2

2A. Leaf-blade with irregularly scattered spots

.f. costatum

2B. Leaf-blade without spots

..f. immaculatum

1B. Leaf-blade with a green midrib.

3A. Leaf-blade heavily and irregularly blotched. ..f. virescens

3B. Leaf-blade not variegated.

f. concolor

This formal concept was accepted in different botanical studies in Indochina, e.g. Newman et al. (2007), Nguyen \& Vu (2009), Van (2017) and Nguyen (2017). Recently, in their treatment of Thai Araceae, Boyce et al. (2012) merged the four forms in A. costatum but no justification was mentioned; this approach seems to be followed in Korea National Arboretum (2016), Roskov et al. (2018) and WCSP (2019). Until the phylogenetic relationship among the forms is studied, the formal delimitation by Nicolson (1969) appears to be judgeable and it is followed in this paper.

In Vietnam, A. costatum has been reported with form immaculatum from Kon Tum and Gia Lai Provinces and the autonymous form costatum from Quang Tri and Dak Lak Provinces (Nguyen \& Vu 2009; Nguyen, 2017; Van, 2017). The species was listed in Pham-Hoang (1991 \& 2000) as a cultivated plant but its description and illustration obviously match the form immaculatum.
Our recent field trip in Phong Nha-Ke Bang National Park, Quang Binh Province encountered a flowering and fruiting population of $A$. costatum with plain green leaves that perfectly match the type specimen and Nicolson's description of form concolor, which has been found in Laos, Malaysia and Thailand (Newman et al., 2007; Nicolson 1969). As result, form concolor is reported here as a new record for the flora of Vietnam.

\section{MATERIALS AND METHODS}

Samples of the newly recorded form were collected from Phong Nha-Ke Bang National Park, Quang Binh Province, Vietnam, on 9 January 2018, at approximate coordinates $17^{\circ} 24^{\prime} 16^{\prime \prime} \mathrm{N}, \quad 106^{\circ} 13^{\prime} 13^{\prime \prime} \mathrm{E}$ and $710 \mathrm{~m}$ elevation. The vouchered specimens (Luu Hong Truong, Truong Quang Cuong, Bui Ngoc Thanh \& Le Canh Nam Luu 1178) are deposited at SGN.

Specimens were sampled and processed using conventional methods guided by the Royal Botanic Gardens, Kew (Bridson \& 
Forman, 1999). Detailed photographs and description of taxonomically important characters of the newly recorded form were taken of fresh materials in the field using a digital camera. Taxonomic identification was done using morphological vegetative and reproductive characters following the aforementioned literature, especially Nicolson (1969).

\section{RESULTS AND DISCSUSSION}

\section{Key to the known taxa of Aglaonema in Vietnam}

Based on Nguyen (2017), Nicolson (1969), Van (2017) and the authors' field observations, the known Vietnamese taxa of Aglaonema can be distinguished by the following key:

1A. Stem repent, frequently branching; petiole sheath less than $1 \mathrm{~cm}$ long; cataphylls subtending the petioles

Section Chamaecaulon

2A. Cataphyll subtending petiole/peduncle usually drying-persistent; leaf base usually obtuse to subrounded.

A. brevispathum

2B. Cataphyll subtending petiole/peduncle usually immediately deliquescent; leaf base subcordate to rounded

3A. Leaf blade with a green midrib

A. costatum f. concolor

3B. Leaf blade with a white midrib

4A. Leaf blade with scattered spots

A. costatum f. costatum

4B. Leaf blade without spots

A. costatum f. immaculatum

1B. Stem erect, rarely decumbent, rarely branching; petiole sheath usually more than $1 \mathrm{~cm}$ long; cataphylls rarely among the petioles

Section Aglaonema

5A. Spadix sessile, female zone adnate to spathe

6A. Female and female zone separated by staminate flowers

A. ovatum

6B. Not above

A. modestum

5B. Spadix stipitate, female zone free from spathe

7A. Plant up to $40 \mathrm{~cm}$ high; venation undifferentiated; peduncle as long as or longer than petiole. A. cochinchinense

7B. Plant up to $1.2 \mathrm{~m}$ high; venation differentiated; peduncle much shorter than petiole. A. simplex

\section{Description of the newly recorded taxon}

Aglaonema costatum f. concolor Nicolson, 1969. Smithsonian Contr. Bot.1: 24 (Fig.1).

Herb evergreen, $15-30 \mathrm{~cm}$ high, solitary to clump-forming. Stem repent and branching, $1-1.2 \mathrm{~cm}$ in diameter; internodes $1-2 \mathrm{~cm}$ long; cataphylls subtending petiole and immediately deliquescent. Leaves several together; petioles $12-20 \mathrm{~cm}$ long, ca. $4 \mathrm{~mm}$ in diameter at base, ca. $8 \mathrm{~mm}$ near leaf blade, dark green, petiolar sheath short, about $1 / 10$ times as long as the petiole length, $1.2-2 \mathrm{~cm}$ long, dark brown; leaf blade ovate, $12-16 \mathrm{~cm}$ long, 3-6 cm wide, coriaceous, base unequal, subcordate to rounded, apex acute to abruptly acuminate, apiculate, dark green on both sides and not variegated; midrib impressed adaxially and prominent abaxially, plain dark green, lateral veins diverging from the midrib and toward margin. Inflorescence solitary; peduncle $8-12 \mathrm{~cm}$, ca. $4 \mathrm{~mm}$ in diameter, green; cataphylls 2, subtending peduncle, 2.5$3 \mathrm{~cm}$ long, with acute apex, immediately deliquescent; spathe shorter than spadix, ca. $3.5 \mathrm{~cm}$ long, ovate, apiculate, spreading at staminate anthesis, pale green on both sides at young, yellow-green at anthesis; spadix 
exceeding spathe, ellipsoidal-cylindrical, ca. 5 $\mathrm{cm}$ long, ca. $1 \mathrm{~cm}$ in diameter, stipitate, stipe ca. $1 \mathrm{~cm}$ long, ca. $3 \mathrm{~mm}$ in diameter, pale green; female zone very short with 1-2 whorls of flowers, ca. $0.5 \mathrm{~cm}$ long, ca. $1 \mathrm{~cm}$ wide; ovaries bottle-shaped, translucent white, ca. 2 $\mathrm{mm}$ in diameter, 1-locular, ovule 1; stigma born on a $1 \mathrm{~mm}$ long style, yellow, subrounded, concave at center, ca. $2 \mathrm{~mm}$ in diameter; male zone ca. $3 \mathrm{~mm}$ long, ca. $1 \mathrm{~mm}$ wide, white, subcylindrial, thecae oblong, dehiscing by apical pore. Fruits ellipsoid, 8 $\mathrm{mm}$ long, $5 \mathrm{~mm}$ in diameter, 1 -seeded, green when young, yellow when ripe; seeds oblanceolate, 4-5 $\mathrm{mm}$ long, $2.5 \mathrm{~mm}$ in diameter.
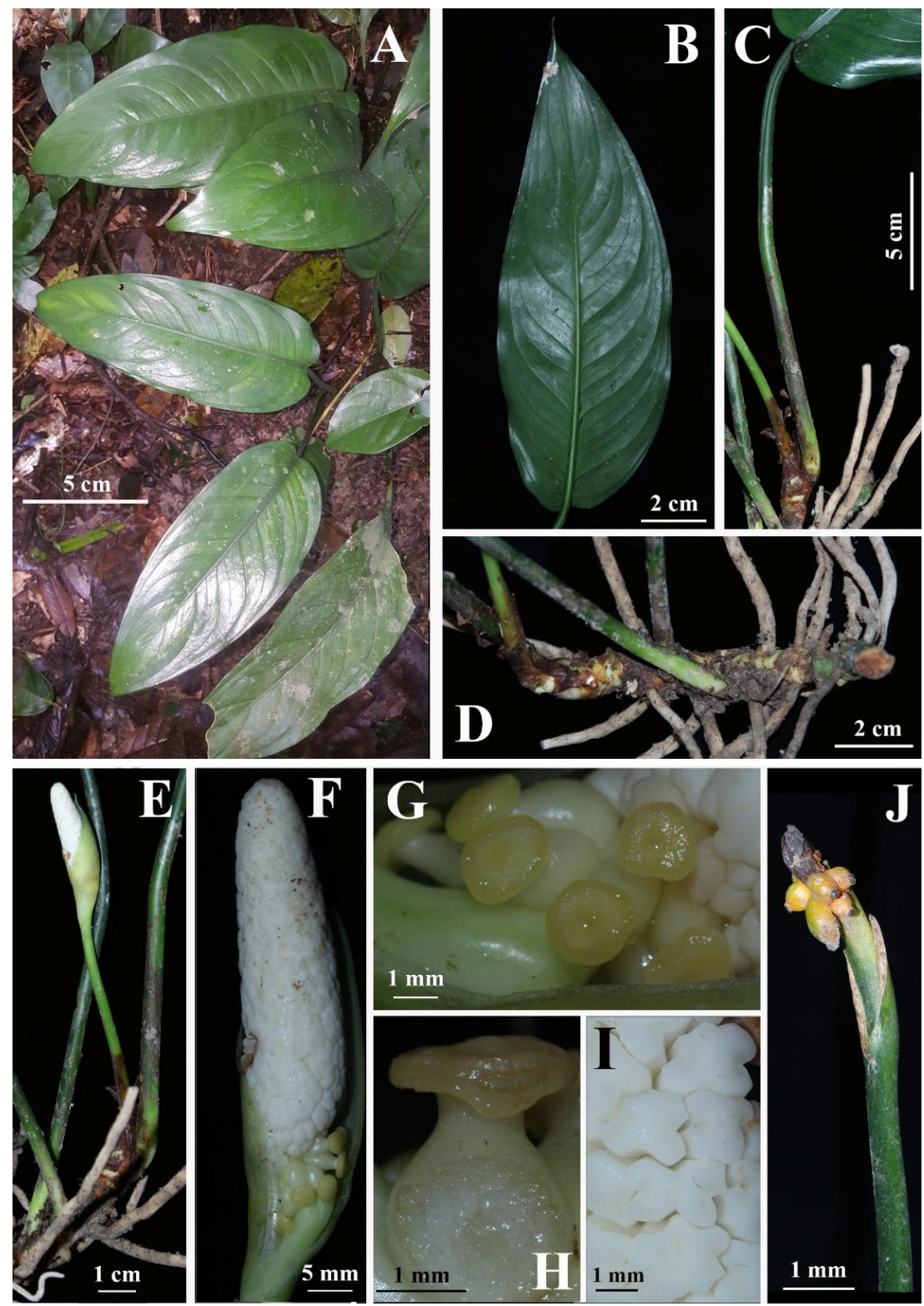

Figure 1. Aglaonema costatum f. concolor. A. Habit and leaf blade (above side). B. Leaf blade (under side). C. Petiole. D. Stem. E. Inflorescence. F. Spadix. G. Female flowers. H. Longitudinal section of ovary. I. Synandria. J. Infructescence 
Typus: Malaya, Kedah, P. Langkawi, Selat Panchor, 21 November 1934, Henderson s.n. (SING).

Ecology: Aglaonema costatum f. concolor is found in evergreen forest on fertile soils on limestone bedrock. Flowers and mature fruits were found in January and thus flowering may appear several months before.

Acknowledgements: The authors of this paper would like to thank Mr. Le Thanh Tinh, Director of Phong Nha - Ke Bang National Park, and Mr. Cao Thai Hung, staff of the park, for their permission and supports for the field work. We are grateful to Serena Lee (SING) for help in taking photo of the type specimen. The anonymous reviewers are thanked for their comments that helped improve our manuscript.

\section{REFERENCES}

Bridson D., Forman L., 1999. The Herbarium Handbook - Third Edition. Royal Botanic Gardens, Kew, UK.

Boyce P. C., Sookchaloem D., Hetterscheid W. L. A., Gusman G., Jacobsen N., Idei T., Nguyen V. D., 2012. Araceae. Flora of Thailand, 11(2): 101-321.

Korea National Arboretum, 2016. A Checklist of Plants in Lao PDR. Published by Korea National Arboretum of Korea Forest Service, Korea.

Nguyen V. D., 2017. Flora of Vietnam Araceae Juss. Publishing House for Science and Technology, vol. 16: 133-147.

Nguyen V.D., Vu T.C., 2009. New discoveries in the family Araceae in Indochina over the past twenty years. In: Proceedings of the Third National Conference on Ecology and Biological
Resources, 22 October 2009. Ha Noi, Vietnam. Pp. 87-92. Agriculture Publishing House, Hanoi, Vietnam. (In Vietnamese with English summary).

Nicolson D. H., 1969. A revision of the genus Aglaonema. Smithsonian Contributions to Botany, 1: 1-69.

Pham-Hoang H., 1991. Araceae. An Illustrated Flora of Vietnam, Tome III, 1: 416-453. Published by the author. Mekong Printing. Montréal. (In Vietnamese with English summary).

Pham-Hoang H., 2000. Araceae. An Illustrated Flora of Vietnam, vol. 3: 334367. Youth Publishing House, Ho Chi Minh City, Vietnam. (In Vietnamese with English summary).

Roskov Y., Abucay L., Orrell T., Nicolson D., Bailly N., Kirk P.M., Bourgoin T., DeWalt R.E., Decock W., De Wever A., Nieukerken E. van, Zarucchi J., Penev L. (eds), 2018. Species 2000 \& ITIS Catalogue of Life, 2018 Annual Checklist. Digital resource at www.catalogueoflife.org/annual-

checklist/2018. Species 2000: Naturalis, Leiden, the Netherlands. ISSN 2405884X.

Van H.T., 2017. Building phylogenetic trees for the Araceae in southern Vietnam based on morphological and molecular markers. $\mathrm{PhD}$ thesis. Graduate University Science and Technology, Vietnam Academy of Science and Technology.

WCSP, 2019. World Checklist of Selected Plant Families. Facilitated by the Royal Botanic Gardens, Kew. Published on the Internet; http://wcsp.science.kew.org/ Retrieved 8 March 2019. 